Nihon Biseibutsu Seitai Gakkaiho

(Bulletin of Japanese Society of Microbial Ecology)

Vol. 3, No. 1, 47-57, 1988

Mini-Review

\title{
Response of Microbial Communities to Heavy Metal Contamination in Soils
}

\author{
Hiroshi OHyA* and Yutaka KomaI \\ Department of Agricultural Chemistry, University of Osaka \\ Prefecture, Sakai, Osaka 591, Japan
}

\begin{abstract}
Ecological assessment, needed for the establishment of admissible dose and the persistence of the effects of heavy metals on microbial communities is reviewed with reference to recent research. Developing concepts for ecological assessment give most emphasis to the exposure time to metals and to qualitative changes in the microbial communities. The potential ability of microbial communities for the development of metal-tolerant microflora should be considered carefully in relation to the exposure time. In this sense, studies on the qualitative changes in bacterial communities after heavy metal contamination, with consideration of the phylogenical relationships between the species, should provide valuable information for better interpretations and the identification of general principle in the potential ability of bacterial communities. In addition, analytical methods for the estimation of the bioeffective amount of heavy metals, which are surely necessary for the establishment of the admissible dose and the comparison of observed effects, were also reviewed.
\end{abstract}

Key words : Heavy metals, ecotoxicological assessment, bacterial flora, cellular fatty acids

\section{Introduction}

Some heavy metals are essential micronutrients for plants, and the earliest studies about their availability were done from the viewpoint of plant nutrition. In industrial countries, however, heavy metal contamination of soils is a serious form of environmental pollution because such metals readily accumulate there and their influence on living organisms may last for a long time. Sewage sludge and industrial wastes containing high concentration of metals are being put to use in agriculture, so heavy metal contamination of soils is of much importance. Soils that have been treated with metal-contaminated sludge contain less microbial biomass and have lower microbial activity than similar soils treated with farmyard manure

* Corresponding author: Hiroshi Ohya
(Brookes and McGrath, 1984; Brookes et al., 1984). These effects are readily detected even though the last sludge application was more than 20 years ago. Contaminated field soils now contain metals at about the current maximum levels specified in the U.K. (U.K. Department of the Environment, 1981). Consequently, heavy metal contamination often occurs not only near mining sites or smelters but also in arable land treated with sewage sludge and even in urban soils through air pollution from factories, cars, etc. (Komai, 1981). Heavy metal contamination of soils has been spreading and its sources are of a wider variety than ever before.

The significance of heavy metal contamination in soils cannot be evaluated without the elucidation of its effects on organisms. Soil microorganisms are particularly sensitive towards heavy metals. In early studies, the effects of heavy 
metals on soil microorganisms were investigated in terms of the scale of biological responses to them. The quantitative effects of heavy metals on microbial functions and population itself have been extensively studied. The qualitative effects of heavy metals on microbial flora have been also investigated and the potential ability of microbial communities to develop metal-tolerant microflora has been held to be important for the ecological assessment of the persistency of the effects. Domsch (1984) has speculated that the evaluation of the ecotoxicological effects of these toxicants may be difficult as long as the potential ability of microbes for restitution and repair is not exhausted. Tiller (1986) has reviewed the heavy metal contamination of soils in relation to its ecological effects.

On the other hand, studies on the effects of heavy metals for the ecological assessment alone will not provide accurate interpretation or make possible an approach to general principles about the potential ability. We have been investigating the qualitative differences in soil bacterial flora, based on the fatty acid composition of bacterial cells, and the microbial shifts for metal tolerance in terms of the phylogenical relationships between bacteria (Ohya et al., 1986; 1987). Analysing the direction and extent of the microbial shifts in the community will provide a possible approach to principles.

The observed toxicity of heavy metals is dependent on many environmental factors, which makes it difficult to establish sound, uniform guidelines and to compare the results obtained with those in the literature. In particular, important factors that decide toxicity are soil $\mathrm{pH}$, cation-exchange capactiy, clay content, organic matter content, and so on. The solubility, complexation, precipitation, and ion-exchange properties of heavy metals, which influence their toxicity, were reviewed by Matthess (1984). Analytical methods for estimating the bioeffective amounts of heavy metals are being developed.

In this report, the ecological assessment of heavy metal toxicity toward soil microbial communities and analytical methods for the estimation of bioeffective heavy metals are reviewed with reference to recent papers. Our new approach to general principles about the qualitative effects of heavy metals on bacterial communities will be discussed.

\section{Ecological assessment of heavy metal effects on microbial communities}

\section{Investigation indices for the assessment}

The investigation indices can be roughly divided into two types, quantity and quality, one of which involves the functions of microbial communities as a biological process or population itself, including biomass, and the other of which involves the shift in microflora toward the development of metal tolerance. More sensitive indices have been developed for the assessment of low level contamination.

Considering soil productivity, aspects of the Cand $\mathrm{N}$-cycles as a biological process should have the highest priority. The effects of heavy metals on aspects of the $\mathrm{C}$-cycle such as soil respiration and the decomposition of exogenous organic compounds (e.g., Chang and Broadbent, 1981 ; Lighthart et al., 1983; Ohya et al., 1985) have been extensively studied, and so have aspects of the $\mathrm{N}$-cycle such as $\mathrm{N}_{2}$-fixation, ammonification, and nitrification (e.g., Liang and Tabatabai, 1978; Mathur and Preston, 1981; Rother et al., 1982). In particular, soil respiration reflecting the overall mineralization process is one of the indices most often used in enviromental assessment. Skujiňs et al. (1986) studied the toxic effects of $\mathrm{Cu}$ and $\mathrm{Cr}$ (III) on soil respiration, urease, nitrification, and non-symbiotic $\mathrm{N}_{2}$-fixation, and found that $\mathrm{N}_{2}$ fixation is the most sensitive index. Haanstra and Doelman (1984) discussed the use of glutamic acid decomposition time (the time required to reach the maximum respiration rate) as a sensitive index of heavy metal contamination of soils.

Soil enzymes, which are involved in specific 
steps of biological processes, have been also used to measure the effects of heavy metals as more sensitive indices. Acetate incorporation and glucosidase activity methods for such assessment were described by Barnhart and Vestal (1983). Krasnova (1983) suggested the use of soil urease and invertase activities as an index of heavy metal contamination. The application of $\mathrm{Fe}, \mathrm{Cu}$, or $\mathrm{Zn}$ at $20 \mu \mathrm{g} / \mathrm{g}$ soil to eight Spanish soils resulted in 7$20 \%$ inhibition of urease activity (Daif and Van Beusichem, 1981). Chou and Zhang (1984) reported the effects of $\mathrm{Hg}, \mathrm{Cd}$, and $\mathrm{Pb}$ on the activities of catalase, invertase, urease, and phosphatase in fertile and infertile brown earths and krasnozems.

Population studies on the effects of heavy metals on communities of bacteria (e.g., Doelman and Haạnstra, 1979; Bardos and Edwards, 1984), actinomycetes (e.g., Jordan and Lechevalier, 1975 ; Coughtrey et al., 1980), and fungi (e.g., Nordgren et al., 1983; Yamamoto et al., 1981 ; 1985) have been actively made. Usually, coupled with the population studies, the sensitivity of microorganisms towards heavy metals is also investigated. In a study of bushland soil, Duxbury (1981) described the toxicity of various metals toward bacterial communities by a single exponential equation and, later, a second function was also reported by Duxbury and Bicknell (1983). They suggested that bacterial communities from either natural and metal-contaminated soils have two subgroups, one of which can tolerate heavy metals over a greater range of concentrations than the other. Olson and Thornton (1982) studied the resistance of soil bacterial communities to heavy metals, and proposed that the tolerance of bacteria to metals is used to evaluate the bioavailability and potential toxicity of these metals to other forms of life. Niyazova et al. (1983) reported on the threshold concentrations of $\mathrm{Pb}$ and $\mathrm{Zn}$, defining the range of concentrations that do not suppress growth, in soil microorganisms.

In addition, studies on the structure (relative degree of dominance of the numbers) and composition (list of species) of microbial communities provide useful information for the elucidation of qualitative changes in the communities and for the selection of indicator microorganisms. In $\mathrm{Pb}$ contaminated soils, more Gram-negative rods are present than in uncontaminated soil and a high proportion of them are Pb-tolerant strains (Doelman and Haanstra, 1979). Duxbury and Bicknell (1983) investigated the toxicity of several metals towards bacterial communities from natural and metal-contaminated soils and obtained similar results. Olson and Thornton (1982) found that bacteria from Shipham soil isolated on medium with $\mathrm{Cd}$ added were often limited to species of two to four genera of Alcaligenes, Pseudomonas, Flavobacterium, and Acinetobacter. Pseudomonas was found to be predominant in contaminated water and sediments (Austin et al., 1977; Houba and Remacle, 1980). For fungal communities, Yamamoto et al. (1985) observed that the genus Penicillium may be dominant in soils found near mines and contaminated with $\mathrm{Cu}$. In Gusum soils near a brass mill, Mortierella was most frequently isolated in moderately contaminated sites (mainly with $\mathrm{Pb}$ and $\mathrm{Zn}$ ), and Geomyces and Paecilomyces increased in abundance along a gradient of heavy metals (Nordgren et al., 1983). Niyazova et al. (1983) reported that darkpigmented fungi of the genus Cladosporium may serve as indicators of soil contamination by $\mathrm{Zn}$, $\mathrm{Pb}$, and $\mathrm{Cu}$.

Population studies are usually done with the dilution plate count technique, so the physiological state of the microorganisms in the soil is often disregarded. Viable counts on medium plates without metals added may therefore produce misleading results such as the overestimation of microbial population and the apparent predominance of certain species. The physiological effects of heavy metals are of particular importance in low level contaminated soils. Concerning physiological effects on microorganisms, Killham (1985) suggested the use of the ratio of respired $C$ : biomass-incorporated $\mathrm{C}$ as a sensitive index of environmental toxicants, including heavy metals. 
The effects of heavy metals on the microbial biomass have been investigated (e.g., Brookes and McGrath, 1984; Brookes et al., 1986; Ohya et al., 1988). From the physiological point of view, the microbial biomass mainly reflects the size of the actively metabolizing microbial population.

\section{Ecological concepts for the assessment}

In the ecological assessment of the effects of heavy metals, the potential ability of microbial communities for the development of metal-tolerant microflora is of outstanding weight. Consequently, exposure time to heavy metals should be considered carefully.

Based on a theoretical proposition about the microzonality of microbiological processes in soils, an attempt to interpret the microbial response to heavy metal contamination has been made by Guzev et al. (1985), who studied the effects of $\mathrm{Pb}$ and $\mathrm{Cd}$ on the structure and composition of a soil amylolytic microbial community. According to the response of the community, they proposed four qualitatively different zones: homeostasis, stress, resistance, and repression zones. In the homeostasis zone, the structure and the composition of the microbial community are stable, and virtually indistinguishable in these respects to the community of the control soil. In the stress zone, the composition of the community remains practically unchanged while the structure undergoes considerable change. In this zone, there is a redistribution of the population in terms of the degree of dominance. In the resistance zone, there is a sharp reduction in the species diversity and a change in the composition of the community. This zone is characterized by lack of change in the total biomass of the microorganisms in the community because to the development of metal resistance. In the repression zone, one observes virtually total suppression of the growth and development of microorganisms in the soil. Domsch et al. (1983) have proposed that microbial responses to various toxicants be put into three categories: negligible, tolerable, and critical.
In their concept, the exposure time to toxicants is of most importance in terms of the potential ability of microbial communities for tolerance. With persistent toxicants such as heavy metals, the ecological implications seem clear from the viewpoint of the persistency of the effects, but their validity must be examined critically.

In the report of Guzev et al. (1985), qualitative changes in the amylolytic microbe community are investigated in detail, but the time factor is not discussed explicitly. Yamamoto et al. (1985) studied the development of a Cu-tolerant community of fungi with the exposure time to the metal, and reported that a biological equilibrium is not established, giving a "climax" community, for 5 months. On the other hand, in a concept described by Domsch et al. (1983), the time factor can be considered with special regard to the potential ability for metal tolerance. In their concept, however, the evaluation of qualitative changes in microbial communities is not possible, because the concept has quantitative indices such as microbial functions or populations as the assessable indices. Recently, Doelman and Haanstra (1986) investigated the changes in soil-urease activity caused by the toxic effects of six metals versus the exposure time to them, and found that the toxic effects of $\mathrm{Cd}, \mathrm{Cu}$, and $\mathrm{Zn}$ tend to increase over 18 months, whereas those of $\mathrm{Ni}$ and $\mathrm{Pb}$ are constant, in three soil-type samples. At any rate, these concepts should be useful for the ecological assessment of heavy metal effects and for decisions about the area of future studies.

\section{Ecological approach to general principles of the qualitative effects on bacterial community}

\section{Characterization of bacteria by their fatty acid composition}

Bacterial communities in soils are much affected by heavy metal contamination, as shown in the literature cited here. The structure and composi- 
tion of the community are drastically altered by metals. However, reports on the effects of heavy metals on these changes in the community are still limited. Almost all the existing reports ignore the exposure time to heavy metals and simply describe the identification of the bacterial species after a fixed monitoring period. One important aspect of the time factor is to sudy successive transitions of predominant species during the period of monitoring, and another is to study the direction and extent of bacterial shifts in the community with respect to phylogeny. Studies on the natural or evolutional relationships between bacterial species will make possible an approach to the prediction of bacterial shifts.

For the recoginition of shifts in the bacterial community, it is necessary to characterize and distinguish between isolated bacteria. Current methods in diagonostic microbiology for the identification of bacteria are based on the morphological, physiological, biochemical, and immunological characteristics of microorganisms, among other things. These methods, however, are not always adequate from the phylogenical point of view (Ueta et al., 1970). The characterization of bacteria by differences in their chemical composition, for example, by the principal amino acid in the cell wall, the DNA base composition (GCcontent of the DNA), isoprenoid quinones, and fatty acid composition, should provide information needed for the differentiation and classification of bacterial groups from this point of view (Ueta et al., 1970; Katayama-Fujimura et al., 1982). Rapid methods of chemical analysis may provide means to shorten the identification time (Anhalt, 1975).

We think that the fatty acid composition of soil bacteria gives valuable information for their characterization and for differentiation between them, and may be applicable to ecological studies of soil bacteria. The ecological usefulness of the bacterial fatty acid composition has been confirmed in marine sediment (Boon et al., 1977; Yamaoka and Tanimoto, 1977). In addition, the earliest numerical technique used for bacterial taxonomy was developed as the numerical taxonomy of Sneach (1957). This taxonomic method has helped to clarify the genetic relationships between bacteria. The adoption of appropriate criteria in numerical methods should provide information about the relationships. Cluster analysis of fatty acid composition is useful for the identification of relationships between isolated bacteria and, consequently, will be helpful in the study of the qualitative effects of heavy metals on bacterial communities.

\section{Case studies on relationships between bacterial communities in soils contaminated with zinc}

In a first attempt, we tried to demonstrate qualitative changes in a bacterial community of heterotrophic aerobes caused by the addition of a heavy metal to a soil (as $\mathrm{ZnCl}_{2}, 1000 \mu \mathrm{g} \mathrm{Zn} / \mathrm{g}$ soil), by analysis of the cellular fatty acid composition of isolated bacteria, and we monitored the successive changes of the predominant bacteria (Ohya et al., 1986). Based on similarites (evaluated by the $r$ level) in fatty acid composition, cluster analysis was used to obtain information on relationships between bacterial groups (defined at the $0.95 r$ level) isolated from the same two soils (Ohya et al., 1987).

Figure 1 shows the relationships of the predominant bacterial groups detected in this study.

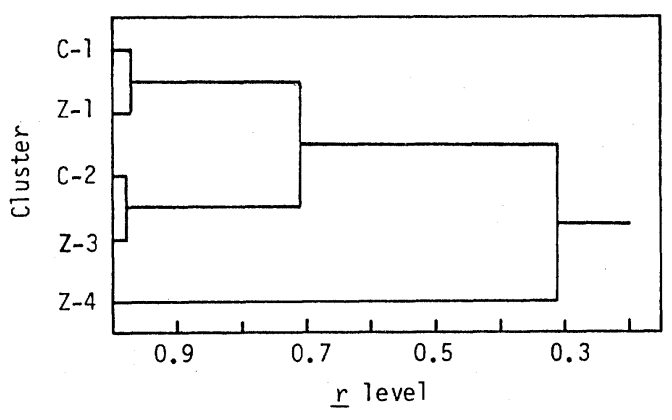

Fig. 1. Dendrogram showing the relationships between predominant clusters obtained from a bacterial community in a soil with or without added $\mathrm{Zn}$. 
Clusters C-1 and C-2 were the predominant bacterial groups isolated from the soil incubated without added $\mathrm{Zn}$. Cluster $\mathrm{C}-1$ became predominant early in the incubation for $96 \mathrm{hr}$, followed by Cluster C-2. In contrast, Clusters Z-1, Z-3, and Z-4 were the predominant groups in the soil with added $\mathrm{Zn}$, and became predominant in this order during the incubation. Bacterial groups of these $\mathrm{Z}$-clusters were $\mathrm{Zn}$-tolerant bacteria except for Cluster Z-1. A bacterial group belonging to Cluster Z-1 was identified as being of the genus Bacillus, and this predominance may have been an artifact because of the presence of the strain as spores in the soil. Cluster Z-3 was quite similar to Cluster C-2 and even C-1. However, Cluster Z-4 considerably different from the others. These results suggest that predominant bacterial groups were shifted to both significantly similar and dissimilar groups in the presence of $\mathrm{Zn}$. With increasing exposure time to $\mathrm{Zn}$, the similarity of the predominant groups decreased.

For further identification of qualitative changes in communities, urban soils with $\mathrm{Zn}$ contamination of long standing (more than 20 years) were studied. Three $\mathrm{Zn}$-contaminated soils were selected for the investigation from 30 urban soils with one slightly contaminated ( $300 \mu \mathrm{g} / \mathrm{g}$, extractable with $0.1 N \mathrm{HCl}$ ) and two highly contaminated samples (3200 and $4700 \mu \mathrm{g} / \mathrm{g}$, extractable with 0.1

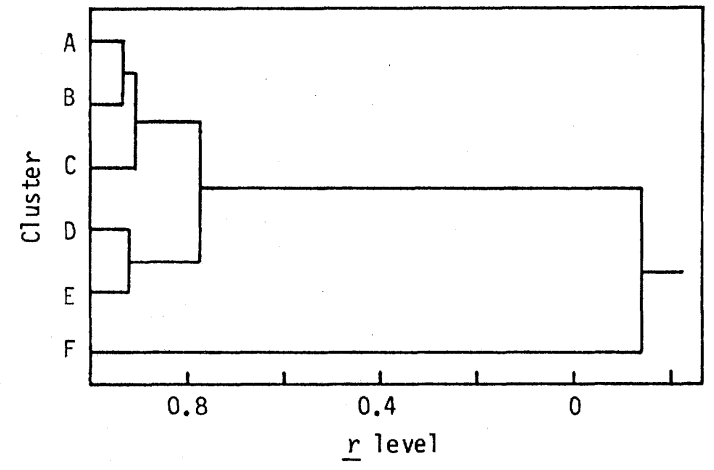

Fig. 2. Dendrogram showing the relationships between predominant clusters obtained from bacterial communities in three $\mathrm{Zn}$-contaminated soils.
$N \mathrm{HCl}$ ). Details of the other soil characteristics of these soils have been described elsewhere (Ohya et al., 1988). Throughout the three contaminated soils, six bacterial groups, named Clusters A to F, were predominant. Figure 2 show the relationships of these predominant groups. Clusters A, $\mathrm{C}$, and $\mathrm{D}$ were predominant in the slightly contaminated soil, Clusters A, B, E, and F in the more highly contaminated soil $(3200 \mu \mathrm{g} / \mathrm{g})$, and Clusters $\mathrm{A}$ and $\mathrm{D}$ in the most contaminated soil $(4700 \mu \mathrm{g} / \mathrm{g})$. All of the clusters predominant in the slightly contaminated soil were similar to each other at the level of $0.77 r$ or more, and the similarity between Clusters $\mathrm{A}$ and $\mathrm{C}$ was at the $0.90 r$ level. Towards Clusters A and B, the similarities of Clusters $\mathrm{E}$ and $\mathrm{F}$, which were found in the more highly contaminated soil $(3200 \mu \mathrm{g} / \mathrm{g})$, were at the 0.77 and $-0.14 r$ levels, respectively. The predominant bacterial groups in the most contaminated soil $(4700 \mu \mathrm{g} / \mathrm{g})$ were classified into the same cluster (A or D) obtained in the slightly

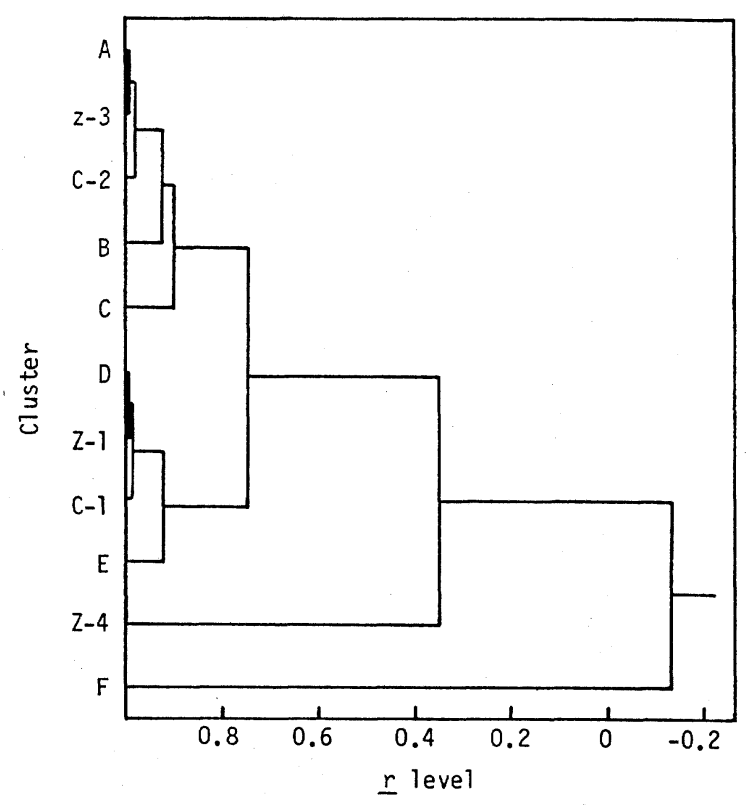

Fig. 3. Dendrogram showing the relationships between predominant clusters obtained from bacterial communities in soils with $\mathrm{Zn}$ contamination that was artificial or of long standing. 
contaminated soil (at more than the $0.95 r$ level), but the $\mathrm{Zn}$ sensitivities were different. These results suggested that the predominant groups of bacterial community are shifted to either significant similarity or dissimilarity.

The relationships of these predominant bacterial groups isolated from artificially (short exposure time) or historically $\mathrm{Zn}$-contaminated soils (long exposure time), in addition to those from the control soil without $\mathrm{Zn}$ added, are shown in Fig. 3. At the $0.90 r$ level, there are four predominant groups : the first group contains Clusters C-2, Z-3, $\mathrm{A}, \mathrm{B}$, and $\mathrm{C}$, the second group contains Clusters $\mathrm{C}-1, \mathrm{Z}-1, \mathrm{D}$, and $\mathrm{E}$, and the third and the fourth groups are Clusters Z-4 and F, respectively. The results also support our suggestion made above, and may be related to the development of a metal-tolerant community. The development of metal-tolerant communities is generally assumed to be due to the ecological selection of inherently metal-tolerant bacterial groups, to the biological adaptation or mutation of the original groups, or to a combination of both. Compared with the predominant groups in the control soil, the bacterial shifts to significant dissimilar groups, which suggest the ecological selection of metal-tolerant bacteria rather than the biological adaptation or mutation of the original groups, are considered to be associated with the exposure time or the bioeffective amount of metal. It can be assumed that the similarity of these groups decreases with the exposure time or an increase in the bioeffective metal. In contrast, shifts to similar groups, which suggest biological adaptation or mutation rather than ecological selection, may occur without strong dependence on the exposure time and the bioeffective metal. The metal sensitivity of these groups is anticipated to be related not only to the bioeffective amount of metal but also to the exposure time. However, the validity of these suggestions must be critically examined by further study on the bacterial community in many soils contaminated with heavy metals.

\section{Estimation of bioeffective heavy metals}

The toxicities of heavy metals are influenced by the soil environment. Major factors that decide toxicities are soil $\mathrm{pH}$, cation-exchnge capacity, and the amounts and properties of soil organic matter and clay minerals. Tyler (1981) reviewed the soil factors involved in influencing the toxicities. Metal ions can be complexed with clay particles and organic compounds, thereby reducing their toxicities. On the other hand, the toxicities are increased by lowering soil $\mathrm{pH}$. The solubility of metal ions into soil solution may be strongly associated with their toxicities. The toxic effects of heavy metals on microbial communities cannot be discussed in terms of the total amount of metals alone, and the amounts of bioeffective heavy metals should be estimated definitely for the establishment of their guidelines in soils and the comparison of observations in the literature.

The bioeffective amount of heavy metals in soils has often been estimated through correlations between metals extracted from soils with various solvents and the amount of metals taken up by test plants. Heavy metals are potential toxicants as well as sometimes $(\mathrm{Cu}, \mathrm{Zn}, \mathrm{Mn}$, etc. $)$ being micronutrients for organisms, including plants. Many workers who started to investigate the bioeffective amounts of heavy metals used the same solvents to extract the metals as were used in the micronutrient studies for plants, as related to deficiencies of those elements. In Japan, a $\mathrm{HCl}$ solution $(0.1 \mathrm{~N})$ is recommended as an efficient solvent by govermental ordinance. In field soils contaminated with $\mathrm{Cu}$, total and $\mathrm{Cu}$-tolerant populations of fungi are positively correlated with the $\mathrm{Cu}$-concentration estimated with the $\mathrm{HCl}$ solution, but those of bacteria were not significantly correlated (Yamamoto et al., 1981; 1985). We could not find significant correlations between total popualtions of microorganisms in urban soils contaminated with $\mathrm{Zn}$ and $\mathrm{Pb}$, either bacteria and fungi, and the $\mathrm{HCl}$-extractable metals, whereas a 
Zn-tolerant population of bacteria was positively correlated (Ohya et al., 1988). The solvent may be suited for use with certain acidic soils. Anderson (1976) reported that heavy metals added artificially to a soil are more loosely bound than metals already present in the soil.

Anyhow, it is doubtful whether solvents appropriate for studies of deficiencies can also be used for studies of excess amounts of heavy metal contamination. Haeni and Gupta (1983) posed a similar question and chose $\mathrm{NaNO}_{3}(0.1 \mathrm{~N})$ as an appropriate extractant for simulation of the availability and absorption of heavy metals by plants when there is an excess. Gupta (1984) extensively investigated the relationships between $\mathrm{NaNO}_{3}$ extractable metal concentrations in soils and the activities and growth of the soil microorganisms, and concluded that uniform guidelines on the maximum tolerable metal load in soils and the bioeffective amount of heavy metals can to a large extent be estimated with data obtained by the use of neutral salt solution solvents such as $\mathrm{NaNO}_{3}$. As an example of such guidelines, the Swiss ordinances on heavy metal contents of soils have been published (VSBo, 1986). As a safety margin, these guidelines could be set at half the proposed maximum tolerable metal load (Gupta, 1984). These guidelines are sufficiently below the admissible dose, which must be lower than the range of concentrations of the homeostasis zone described by Guzev et al. (1985).

The bioeffective amount of heavy metals has been usually assessed in terms of a single metal. However, the soil environment is eften endangered not only by a single kind of heavy metal, but also by the combined effects of several kinds of metals. Synergistic or antagonistic effects of heavy metals on microbial communities may exist; composite effects of metals on isolated bacteria have been reviewed by Gadd and Griffiths (1978) and Sterritt and Lester (1980). Bardos and Edwards (1984) suggested that the combined effects of $\mathrm{Cu}, \mathrm{Pb}$, and $\mathrm{Zn}$ upon the viable count of bacteria are additive rather than synergistic. A similar suggestion was made by Mosey (1976), who investigated heavy metal toxicity in sewage sludge. The existence of mixed heavy metal effects must be critically examined and the possible synergistic effects of metals should be paid much attention to during the assessment.

\section{Concluding remarks}

Heavy metal contamination in soils, even if at low levels, has become widespread with the diversification of contamination sources, and may continue as long as a soil surveillance system is not established. At the very least, soil research on the bioeffective amount of metals should be done at regular intervals. For the establishment of admissible dose, studies on the relationships between the metal effects investigated with sensitive indices such as soil enzyme activities and the bioeffective metals estimated by appropriate solvents such as $\mathrm{NaNO}_{3}$ shoud be useful. The admissible doses should be confirmed by ecological assessments. For this purpose, the persistency of the effects must be critically assessed with ecological concepts that are now being developed. In the ecological concept, the exposure time to metals should be given most emphasis, relating to the potential ability of microbial communities for the development of metal-tolerant microflora. The range of metal concentration in which the development of the metal-tolerant microflora could occur is simply defined as "tolerable" in the present concept. Even in this range, however, the metal-tolerant microflora may be changed not only with the bioeffective amount of metals but also with the exposure time to metals. Better interpretation and the identification of general principles in these qualitative effects should provide more accurate assessment for the persistency of heavy metal toxicity. Qualitative differences in the microflora should be given much attention, and which may be evaluated ultimately as quantitative differences by studies on the physiological properties of the metal-tolerant microorganisms. 
In soils contaminated with heavy metals, detoxification by microorganisms is desirable. The formation of volatile metabolites with certain metals, mainly $\mathrm{Hg}$, Se, and As, may result in the direct removal of the metals from the contaminated soils. The immobilization of metals by microbial cells may be also used for the reduction of the bioeffective amount of metals in the contaminated soils. Detoxification ability of microorganisms should be carefully confirmed in the soils.

\section{References}

Anderson, A., 1976. On the determination of ecologically significant fractions of some heavy metals in soils. Swedish J. Agric. Res., 6, 19-25.

Anhalt, J.P., 1975. Identification of bacteria using mass spectrometry. Anal. Chem., 47, 219-225.

Austin, B., D.A. Allen, A.L. Mills and R.R. Colwell, 1977. Numerical taxonomy of heavy metaltolerant bacteria isolated from an estuary. Can. J. Microbiol., 23, 1433-1447.

Bardos, R.P. and P.J. Edwards, 1984. Some effects of the heavy metal pollution at a Devon mine site on soil bacteria. In : Environmental contamination, pp. 696-701, CEP Consultants, Edinburgh.

Barnhart, C.L.H. and J.R. Vestal, 1983. Effects of environmental toxicants on metabolic activity of natural microbial communities. Appl. Environ. Microbiol., 46, 970-977.

Boon, J.J., J.W. de Leeuw, G.J. Hoek and J.H. Vosjan, 1977. Significance and taxonomic value of iso and anteiso monoenoic fatty acids and branched $\beta$-hydroxy acids in Desulfovibrio desulfuricans. J. Bacteriol., 129, 1183-1191.

Brookes, P.C. and S.P. McGrath, 1984. Effects of metal toxicity on the size of the soil microbial biomass. J. Soil Sci., 35, 341-346.

Brookes, P.C., S.P. McGrath, D.A. Klein and E.T. Elliott, 1984. Effects of heavy metals on microbial activity and biomass in field soils treated with sewage sludge. In : Environmental contamination, pp. 574-583, CEP Ltd., Edinburgh.

Brookes, P.C., C.E. Heijnen, S.P. McGrath and E.D. Vance, 1986. Soil microbial biomass estimates in soils contaminated with metals. Soil Biol. Biochem., 18, 383-388.

Chang, F.H. and F.E. Broadbent, 1981. Influence of trace metals on carbon dioxide evolution from a Yolo soil. Soil Sci,, 132, 416-421.

Chou, L.K. and Z.M. Zhang, 1984. Soil pollution by heavy metals and soil enzyme activity. In :
Recent investigations in the zone of aeration, (edited by P. Udluft, B. Merkel and K.H. Prosl), Vol. 2, pp. 811-822, Technical University of Munich, Munich.

Coughtrey, P.J., M.H. Martin, J. Chard and S.W. Shales, 1980. Micro-organisms and metal retention in the wood louse Onisus asellus. Soil Biol. Biochem., 12, 23-27.

Daif, M.A. and M.L. Van Beusichem, 1981. Effects of some trace elements on urea hydrolysis in soils. Netherland J. Agric. Sci., 29, 247-257.

Doelman, P. and L. Haanstra, 1979. Effects of lead on the soil bacteral microflora. Soil Biol. Biochem., 11, 487-491.

Doelman, P. and L. Haanstra, 1986. Short- and longterm effects of heavy metals on urease activity in soils. Biol. Fertil. Soils, 2, 213-218.

Domsch, K.H., G. Jagnow and T. Anderson, 1983. An ecological concept for the assessment of sideeffects of agrochemicals on soil microorganisms. In: Residue Reviews, Vol.86, pp.66-105, Springer-Verlag, New York.

Domsch, K.H., 1984. Effects of pesticides and heavy metals on biological processes in soil. Plant and Soil, 76, 367-378.

Duxbury, T., 1981. Toxicity of heavy metals to soil bacteria. FEMS Microbiol. Lett., 11, 217-220.

Duxbury, T. and B. Bicknell, 1983. Metal-tolerant bacterial populations from natural and metalpolluted soils. Soil Biol. Biochem., 15, 243-250.

Gadd, G.M. and A.J. Griffiths, 1978. Microorganisms and heavy metal toxicity. Microbial Ecol., 4, 303-317.

Gupta, S.K., 1984. Importance of soil solution composition in deciding the best suitable analytical criteria for guidelines on maximum tolerable load and in assessing bio-significance of metals in soil. Schweiz. Landw. Fo., 23, 209-225.

Guzev, V.S., S.V. Levin and D.G. Zvyagintsev, 1985. Reaction of the microbe system of soils to a heavy-metal concentration gradient. Microbiology, 54, 333-338.

Haanstra, L. and P. Doelman, 1984. Glutamic acid decomposition as a sensitive measure of heavy metal pollution in soil. Soil Biol. Biochem., 16, 595-600.

Haeni, H. and S. Gupta, 1983. Choice of an extractant for simulating the availability and absorption of heavy metals by plants. In : Processing and use of sewage sludge, (edited by $\mathrm{P}$. L'hermite and H. Ott), pp. 387-393, D. Reidel Publishing Company.

Houba, C. and J. Remacle, 1980. Composition of the saprophytic bacterial communities in freshwater systems contaminated by heavy metals. Microbial Ecol., 6, 55-70. 
Jordan, M.J. and M.P. Lechevalier, 1975. Effects of zinc-smelter emissions on forest soil microflora. Can. J. Microbiol., 21, 1855-1865.

Katayama-Fujimura, Y., N. Tsuzaki and H. Kuraishi, 1982. Ubiquinon, fatty acid and DNA base composition determination as a guide to the taxonomy of the genus Thiobacillus. J. Gen. Microbiol., 128, 1599-1611.

Killham, K., 1985. A physiological determination of the impact of environmental stress on the activity of microbial biomass. Environ. Pollut. (Series A), 38, 283-294.

Komai, Y., 1981. Heavy metal pollution in urban soils. In: Heavy metal pollution in soils of Japan, (edited by K. Kitagishi and I. Yamane), pp. 193-217, Japan Scientific Societies Press, Tokyo.

Krasnova, N.M., 1983. Enzymatic activity as a bioindication of heavy-metal pollution of soil. Soviet Agric. Sci., 7, 71-74.

Liang, C.N. and M.A. Tabatabai, 1978. Effects of trace elements on nitrification in soils. J. Environ. Qual., 7, 291-293.

Lighthart, B., J. Baham and V.V. Volk, 1983. Microbial respiration and chemical speciation in metal-amended soils. J. Environ. Qual., 12, 543548.

Mathur, S.P. and C.M. Preston, 1981. The effects of residual fertilizer copper on ammonification, nitrification and proteolytic population in some organic soils. Can. J. Soil Sci., 61, 445-450.

Matthess, G., 1984. Unsaturated zone pollution by heavy metals. In: The unsaturated zone between soil surface and groundwater, (edited by B. Yaron, G. Dagan and J. Goldschmid), pp. 79-93, Springer-Verlag, Berlin.

Mosey, F.E., 1976. Assessment of the maximum concentration of heavy metals in crude sewage which will not inhibited the anaerobic digestion of sludge. Water pollut. Control, 75, 10-20.

Niyazova, G.A., S.V. Letunova and E.A. Volodina, 1983. Sensitivity of microorganisms isolated from soil to zinc and lead. Microbiology, 52, 663-670.

Nordgren, A., E. Bååth and B. Söderström, 1983. Microfungi and microbial activity along a heavy metal gradient. Appl. Environ. Microbiol., 45, 1829-1837.

Ohya, H., Y. Komai and M. Yamaguchi, 1985. Zinc effects on soil microflora and glucose metabolites in soil amended with ${ }^{14} \mathrm{C}$-glucose. Biol. Fertil. Soils, 1, 117-122.

Ohya, H., Y. Komai and M. Yamaguchi, 1986. Zinc effects on a soil bacterial flora characterized by fatty acid composition on the isolates. Biol. Fertil. Soils, 2, 59-63.

Ohya, H., Y. Komai and M. Yamaguchi, 1987. Appli- cation of cluster analysis with fatty acid composition to the bacterial ecology in soil with zinc added. Bull. Jap. Soc. Microbial Ecol., 1, 57-63. (In Japanese with English abstract).

Ohya, H., S. Fujiwara, Y. Komai and M. Yamaguchi, 1988. Microbial biomass and activity in urban soils contaminated with $\mathrm{Zn}$ and $\mathrm{Pb}$. Biol. Fertil. Soils, 6, 9-13.

Olson, B.H. and I. Thornton, 1982. The resistance patterns to metals of bacterial populations in contaminated land. J. Soil Sci., 33, 271-277.

Rother, J.A., J.W. Millbank and I. Thornton, 1982. Effects of heavy-metal additions on ammonification and nitrification in soils contaminated with cadmium, lead and zinc. Plant and Soil, 69, 239-258.

Skujiňs, J., H.Ö. Nohrstedt and S. Odén, 1986. Development of a sensitive biological method for the determination of a low-level toxic contamination in soils. Swedish J. Agric. Res., 16, 113-118.

Sneath, P.H.A., 1957. The application of computers to taxonomy. J. Gen. Microbiol., 17, 201-226.

Sterritt, R.M. and J.N. Lester, 1980. Interactions of heavy metals with bacteria. Sci. Total Environ., 14, 5-17.

Tiller, K.G., 1986. Essential and toxic heavy metals in soils and their ecological relevance. In : Transactions XIII, Congress of the International Society of Soil Science, Plenary Papers, Vol. 1, pp. 29-44, International Society of Soil Science, Netherlands.

Tyler, G., 1981. Heavy metals in soil biology and biochemistry. In : Soil Biochemistry, (edited by E.A. Paul and J.N. Ladd), Vol. 5, pp. 371-414, Mercel Dekker, Inc., New York and Basel.

Ueta, N., I. Ishizuka and T. Yamakawa, 1970. Gas chromatographic grouping of bacteria. In: Proceedings of the first international conference on culture collections, (edited by H. Iizuka, T. Hasegawa, Y. Tsunematsu, T. Nei, Y. Okami, J. Yasuda and E. Yabuuchi), pp. 371-381, Univ. Tokyo Press, Tokyo.

U.K. Department of the Environment, 1981. Report of the sub-committee on the disposal of sewage sludge to land. In : Standing Technical Committee Report, No. 20, National Water Council, London.

VSBo (Verordnung über Schadstoffe im Boden), 1986. Swiss ordinance on heavy metal contents in soils. Bundesrates vom 9, Juni, SR814. 12.

Yamamoto, H., K. Tatsuyama, H. Egawa and T. Furuta, 1981. Microflora in soils polluted by copper mine drainage. Japanese J. Soil Sci. Plant Nutr., 52, 119-124. (In Japanese with English abstract).

Yamamoto, H., K. Tatsuyama and T. Uchiwa, 1985. Fungal flora of soil polluted with copper. Soil Biol. Biochem., 17, 785-790. 
Yamaoka, Y. and T. Tanimoto, 1977. Chemical composition of organic compounds in the sediments of Hiro Bay. Nippon Nogeikagaku Kaishi, 51, 625-
630. (In Japanese with English abstract).

(Received Jan. 4, 1988-Accepted July 3, 1988) 